Article

\title{
Locally Adapted and Organically Grown Landrace and Ancient Spring Cereals-A Unique Source of Minerals in the Human Diet
}

\author{
Eva Johansson*(D), Maria Luisa Prieto-Linde and Hans Larsson
}

Citation: Johansson, E.; Prieto-Linde, M.L.; Larsson, H. Locally Adapted and Organically Grown Landrace and Ancient Spring Cereals-A Unique Source of Minerals in the Human Diet Foods 2021, 10, 393. https://doi.org/ $10.3390 /$ foods 10020393

Academic Editor:

Maria Papageorgiou

Received: 31 December 2020

Accepted: 5 February 2021

Published: 11 February 2021

Publisher's Note: MDPI stays neutra with regard to jurisdictional claims in published maps and institutional affiliations.

Copyright: (c) 2021 by the authors. Licensee MDPI, Basel, Switzerland. This article is an open access article distributed under the terms and conditions of the Creative Commons Attribution (CC BY) license (https:// creativecommons.org/licenses/by/ $4.0 /)$.
Department of Plant Breeding, Swedish University of Agricultural Sciences, P. O. Box 101, 23053 Alnarp, Sweden; maria.luisa.prieto-linde@slu.se (M.L.P.-L.); hans.larsson@slu.se (H.L.)

* Correspondence: Eva.johansson@slu.se; Tel.: +46-40415337

Abstract: Consumer interest in local and organic produce, sustainability along the production chain and food products contributing to health, are laying the foundation for local and organic-based diets using nutrient-dense food. Here, we evaluated 25 locally adapted landrace and ancient spring cereal genotypes per location over four locations and three years, for mineral content, nutritional yield and nutrient density. The results showed a large variation in minerals content and composition in the genotypes, but also over cultivation locations, cultivation years and for genotype groups. Highest minerals content was found in oats, while highest content of $\mathrm{Zn}$ and Fe was found in ancient wheats. The wheat Diamant brun, the wheat landrace Öland and naked barley showed high mineral values and high content of $\mathrm{Zn}$ and Fe when grown in Alnarp. Nutritional yield, of the cereals evaluated here, was high related to values reported internationally but lower than those found in a comparable winter wheat material. The nutrient density was generally high; less than $350 \mathrm{~g}$ was needed if any of the evaluated genotype groups were to be used in the daily diet to reach the recommended value of $\mathrm{Zn}$ and Fe, while if the suggested Novel Nordic Diet mix was used, only $250 \mathrm{~g}$ were needed. A transfer from currently consumed cereals to those in the present study, along the New Nordic Diet path, showed their potential to contribute as sustainable and nutrient-rich sources in the human diet.

Keywords: landrace wheat; naked barley; New Nordic Diet; oats; rye; ancient wheat

\section{Introduction}

Cereals include the major crops grown throughout the globe, grown in principal in all types of climates, with wheat, rice and maize as the outranging largest crops all over [1-3]. In the Nordic hemisphere, the dominating cereals are wheat, barley, oats and rye [4]. Cereals in the Nordic hemisphere, can be grown either as spring or winter types, where the winter types are sown in the autumn, have to survive winter, thereby setting flowers and seeds the following summer, while spring types are sown in the spring and harvested in the coming autumn [5]. Spring cereals are primarily grown due to harsh winter conditions effecting negatively the winter cultivation of cereals [5], although spring types of cereals are also known to hold specific quality attributes, making them of interest for cultivation. Thus, spring wheat sown in the Nordic hemisphere, is known as having superior baking quality/gluten strength as compared to winter wheat [6].

Consumers are increasingly interested in both health related and sustainable aspects of food production and consumption with recent trends focusing on organic products, local production, vegetable/vegetarian/vegan food alternatives etc. [7-12]. Ancient/old cereals e.g., wheat, organically produced have also been indicated to contribute to high contents of health-related compounds (e.g., minerals, phytochemicals), high nutrient density and high mineral nutritional yield as compared to conventionally produced cereals [8,13-17].

Minerals are known as macro (e.g., calcium (Ca), magnesium (Mg) and potassium $(\mathrm{K}))$ and micro minerals or trace elements (e.g., copper $(\mathrm{Cu})$, zinc $(\mathrm{Zn})$, iron $(\mathrm{Fe})$, boron 
(B), selenium (Se)) [18], where specifically Zn and Fe deficiency have been reported as a major problem in the human diet [8]. Due to the fact that cereals are a major part of the human diet, high content of minerals and especially of $\mathrm{Zn}$ and Fe in cereals has the potential to contribute substantially to human health and well-being $[8,13,19-21]$. Thus, minerals content in cereals and cereal-based food have been evaluated in a range of studies [22-27]. Furthermore, large international breeding programs, such as the CIMMYT spring wheat program, has focused on biofortification breeding to combine high yield and wide adaptation with high grain $\mathrm{Zn}$ content and processing quality [28-31]. Content of minerals in the cereals is dependent both of the genotypic background of the cultivar and of the cultivation conditions, e.g., soil, climate and management practices [32]. The majority of studies until now have focused on winter wheat (as a major crop) from conventional cultivation systems (as being dominating), although a higher content of the majority of the minerals, including Fe and $\mathrm{Zn}$, has been indicated for spring than for winter and in organic than in conventionally grown wheat [13]. Generally, limited attention has been paid towards the Nordic hemisphere cereals (barley, oats and rye), spring types of cereals, locally adapted cereals and those grown under organic conditions, despite the increasing consumer interest in local and organic production [9-12]. A comparison of mineral contents in all old Nordic spring cereals (including spring rye and naked barley) grown until the 1950s is basically lacking. Similar content of minerals in oats, barley and wheat grains have been reported [33] and levels similar to feed tables in conventionally genotypes of winter types of barely, maize, oats, rye, triticale and wheat grown in one location [34]. Recent studies have evaluated the nutritional value of "the New Nordic Diet (NND)", with a high content of the Nordic cereals (e.g., rye bread and oatmeal), but also of other food components, such as increased levels of plant foods, foods from seas and lakes and food from the wild $[35,36]$. NND consumption has been shown to decrease mortality rates in Danes [37], and improve blood lipid profile and insulin sensitivity, thereby protecting against cardiovascular diseases [38].

The aim of the present study was to evaluate minerals content in locally adapted landraces and ancient genotypes of spring cereals grown organically in various locations in Sweden. Options of these genotypes as a sustainable and nutrient-rich source of minerals was evaluated and is discussed. The aim was also to evaluate nutrient density and nutritional yield of the genotypes and evaluate the contribution of consumption of these genotypes in the human diet.

\section{Materials and Methods}

\subsection{Spring Cereal Material Produced and Used for the Study}

For the present study, a total of 25 landrace and ancient spring cereal genotypes (Table 1) were grown organically in a completely randomized design with two replications in each of four locations (Ekhaga, Krusenberg, Gotland, Alnarp) and three years (2011-2013) for the present study. Due to the fact that ancient and landrace cereals are not adapted to modern high input cultivation conditions, e.g., high input often results in lodging, such conditions could not be used as a control and were therefore omitted. The spring cereal genotypes were selected so that 12 of the genotypes were the same at all the locations and years, and represented each a different type of spring cereal, i.e., rye, white oats, black oats, hulless oats, barley, hulless 2 row barley, naked 6 row barley, emmer wheat, spelt wheat, landrace wheat, old wheat cultivars (before 1950), later cultivars (1950-1960). The additional 13 genotypes per location were landraces and cultivars of barley oats and wheat locally adapted to that specific locality, with a long history and use in the Nordic climate. The overshadowing problem for spring cereals is a rainfall deficit in May-July. The selection of the plant material was done in order both to have common genotypes to allow comparisons of localities and years, but to also secure opportunities to study and understand local adaptation and what that means for mineral nutritional aspects. The cultivation locations have all been under organic conditions since 2001 and are thoroughly spread over the major cereal production areas of Sweden; Ekhaga $\left(59^{\circ} 49^{\prime} 57^{\prime \prime} \mathrm{N}\right.$, 
$17^{\circ} 48^{\prime} 58^{\prime \prime}$ E), Krusenberg ( $\left.59^{\circ} 44^{\prime} 8^{\prime \prime} \mathrm{N}, 17^{\circ} 38^{\prime} 58^{\prime \prime} \mathrm{E}\right)$, Gotland $\left(57^{\circ} 35^{\prime} 52^{\prime \prime} \mathrm{N}, 18^{\circ} 26^{\prime} 50^{\prime \prime} \mathrm{E}\right)$, Alnarp ( $\left.55^{\circ} 39^{\prime} 27^{\prime \prime} \mathrm{N}, 13^{\circ} 04^{\prime} 51^{\prime \prime} \mathrm{E}\right)$, with different soil characteristics (Table 2). No weed control or fertilizer applications have been used in the trials, with the exception of at Gotland, where farmyard manure was applied in the crop rotation. Planting density used was $200 \mathrm{~kg} \mathrm{ha}^{-1}$, plot size was $24 \mathrm{~m}^{2}$ with a harvest size of $23 \mathrm{~m}^{2}$. Total yield was calculated as $\mathrm{kg} \mathrm{ha}^{-1}$ based on the harvest in grams from the $23 \mathrm{~m}^{2}$. Grain protein concentration was calculated from nitrogen determination on dried samples, applying the Dumas method on a Flash 2000 NC Analyzer (Thermo Scientific ${ }^{\mathrm{TM}}$, Waltham, MA, USA), and using the conversion factor 5.7. Following the methodology adopted in Hussain et al. [13], each genotype evaluated in the present study was divided into one of the following genotype groups; Ancient (emmer and spelt wheat), Barley, Landrace wheat (landraces), Naked barley (hulless barley), Oats (black, white and hulless oats), Rye, Wheat (cultivars).

Table 1. Name, type, origin and place of cultivation of genotypes used in the present study.

\begin{tabular}{|c|c|c|c|}
\hline Genotype & Type & Origin & Place $^{1}$ \\
\hline Algot & Wheat & Cultivar 1953 & $\mathrm{E}, \mathrm{K}, \mathrm{A}$ \\
\hline Alva & Barley & Cultivar 1977 & A \\
\hline Argus & Black oats & Cultivar 1926 & G \\
\hline Atle & Wheat & Cultivar 1953 & G A \\
\hline Atson & Wheat & Cultivar 1954 & A \\
\hline Aurore & Wheat & Cultivar 1929 & K \\
\hline Balder & Barley & Cultivar 1945 & $\mathrm{E}, \mathrm{K}$ \\
\hline Bambu & White oats & Cultivar 1934 & $\mathrm{E}$ \\
\hline Blenda & White oats & Cultivar 1950 & $\mathrm{G}$ \\
\hline Dacke & Wheat & Cultivar 1990 & $\mathrm{E}, \mathrm{K}$ \\
\hline Diamant brun & Wheat & Cultivar 1928 & $\mathrm{E}, \mathrm{K}, \mathrm{G}, \mathrm{A}$ \\
\hline Domen & Barley & Cultivar 1959 & $\mathrm{E}$ \\
\hline Dragon & Wheat & Cultivar 1988 & $\mathrm{G}, \mathrm{A}$ \\
\hline Ella & Wheat & Cultivar 1950 & $\mathrm{E}, \mathrm{K}, \mathrm{G}, \mathrm{A}$ \\
\hline Emmer Gotland & Emmer wheat & Primitive & $\mathrm{E}, \mathrm{K}, \mathrm{G}, \mathrm{A}$ \\
\hline Engelbrekt & Black oats & Cultivar 1924 & $\mathrm{E}, \mathrm{K}, \mathrm{G}, \mathrm{A}$ \\
\hline Extra Klock & Black oats & Cultivar 1955 & $\mathrm{~K}$ \\
\hline Gotlandskorn & Barley & Cultivar 1915 & $\mathrm{G}, \mathrm{A}$ \\
\hline Gullkorn & Barley & Cultivar 1913 & $\mathrm{G}$ \\
\hline Hulless 6row barley & Hulless barley & Genebank & $\mathrm{E}, \mathrm{K}, \mathrm{G}, \mathrm{A}$ \\
\hline Hulless 2row barley & Hulless barley & Genebank & $\mathrm{E}, \mathrm{K}, \mathrm{G}, \mathrm{A}$ \\
\hline Hulless oats & Hulless oats & Genebank & $\mathrm{E}, \mathrm{K}, \mathrm{G}, \mathrm{A}$ \\
\hline Ingrid & Barley & Cultivar 1958 & $\mathrm{E}, \mathrm{K}, \mathrm{G}, \mathrm{A}$ \\
\hline Jusso & Rye & Landrace & $\mathrm{E}, \mathrm{K}, \mathrm{G}, \mathrm{A}$ \\
\hline Kajsa & Barley & Cultivar 1977 & E, K \\
\hline Klock & Black oats & Cultivar 1917 & $\mathrm{~A}$ \\
\hline Kärn & Wheat & Cultivar 1946 & $\mathrm{E}, \mathrm{K}$ \\
\hline Landrace Dalarna & Wheat & Landrace & $\mathrm{E}, \mathrm{K}, \mathrm{G}$ \\
\hline Landrace Halland & Wheat & Landrace & $\mathrm{E}, \mathrm{K}$ \\
\hline Lina & Barley & Cultivar 1982 & A \\
\hline Orion & Black oats & Cultivar 1920 & $\mathrm{E}, \mathrm{K}, \mathrm{G}$ \\
\hline Osmo & Back oats & Cultivar 1921 & A \\
\hline Palu & White oats & Cultivar 1945 & $\mathrm{~A}$ \\
\hline Prins & Wheat & Cultivar 1965 & $\mathrm{E}, \mathrm{G}$ \\
\hline Rika & Barley & Cultivar 1949 & G \\
\hline Seger & White oats & Cultivar 1908 & $\mathrm{~K}, \mathrm{~A}$ \\
\hline Selma & White oats & Cultivar 1970 & A \\
\hline Sisu & White oats & Cultivar 1953 & $\mathrm{E}$ \\
\hline Sol & White oats & Cultivar 1950 & $\mathrm{E}, \mathrm{K}$ \\
\hline Spelt wheat Gotland & Spelt wheat & Spelt & $\mathrm{E}, \mathrm{K}, \mathrm{G}, \mathrm{A}$ \\
\hline Spelt wheat Gotland d & Spelt wheat & Spelt & G \\
\hline
\end{tabular}


Table 1. Cont.

\begin{tabular}{cccc}
\hline Genotype & Type & Origin & Place $\mathbf{1}^{\mathbf{1}}$ \\
\hline Summer oats & White oats & Landrace & $\mathrm{G}$ \\
Svanhals & Barley & Cultivar 1903 & $\mathrm{K}$ \\
Ur Gotland & Black oats & Landrace & $\mathrm{G}$ \\
Walter & Wheat & Cultivar 1972 & $\mathrm{A}$ \\
Virma & White oats & Cultivar 1988 & $\mathrm{E}, \mathrm{K}, \mathrm{G}, \mathrm{A}$ \\
Öland & Wheat & Landrace & E, K, G, A \\
\hline
\end{tabular}

${ }^{1} \mathrm{E}=$ Ekhaga, $\mathrm{K}=$ Krusenberg, $\mathrm{G}=$ Gotland, $\mathrm{A}=$ Alnarp.

Table 2. General characteristics of soil at different locations.

\begin{tabular}{|c|c|c|c|c|c|c|c|}
\hline Location & $\mathrm{pH}^{\mathrm{a}}$ & $\begin{array}{c}\text { Organic } \\
\text { Matter (\%) }\end{array}$ & Clay (\%) & $\begin{array}{c}\mathrm{P}-\mathrm{Al}{ }^{\mathrm{b}} \\
\left(\mathrm{mg} 100 \mathrm{~g}^{-1}\right)\end{array}$ & $\begin{array}{c}\mathrm{K}-\mathrm{Al}{ }^{\mathrm{b}} \\
\left(\mathrm{mg} 100 \mathrm{~g}^{-1}\right)\end{array}$ & FYM $^{c}$ & $\begin{array}{c}\text { Organic } \\
\text { Since }\end{array}$ \\
\hline Ekhaga & $5.7-6.1$ & $7.2-9.8$ & $35-38$ & $6.2-7.1$ & $25-27.8$ & No & 1987 \\
\hline Krusenberg ${ }^{d}$ & 5.8 & 2.0 & 9.0 & 8.0 & 5.0 & No & 2001 \\
\hline Gotland & $7.5-8.3$ & $2.5-3.9$ & $18-20$ & $5.2-9.8$ & $9.1-10.4$ & Applied & 1987 \\
\hline Alnarp & $7.3-7.8$ & $3.1-4.5$ & $18-22$ & $7.7-26.7$ & $10.2-18.7$ & No & 1992 \\
\hline
\end{tabular}

${ }^{\mathrm{a}}$ from soil-water sample; ${ }^{\mathrm{b}} \mathrm{P}-\mathrm{Al}$ and K-Al methods used [39]; ${ }^{\mathrm{c}}$ Farm yard manure; ${ }^{\mathrm{d}}$ Only one soil sample was analyzed from this location.

\subsection{Mineral Analyses}

Mineral analyses was carried out according to Hussain et al. [13]. Thus, about $12 \mathrm{~g}$ of each grain sample (whole grain) was milled for $2 \times 10 \mathrm{~s}$ in a laboratory mill (Yellow line, A10, IKA-Werke, Staufen, Germany). Thereafter, the flour samples were stored at $-20^{\circ} \mathrm{C}$ until drying and digestion. The samples were dried at $40{ }^{\circ} \mathrm{C}$ for $24 \mathrm{~h}$ in an oven, and $0.5 \mathrm{~g}$ of the dried flour was digested with $10 \mathrm{~mL}$ of concentrated nitric acid in a microwave (MARS 5, CEM Corporation, Mathews, NC, USA). The digested samples were diluted with pure Milli $\mathrm{Q}$ water to $100 \mathrm{~mL}$ before analysis.

Then, an Inductively Coupled Plasma Atomic Emission Spectrometer (ICP-OES; OPTIMA 8300, Perkin-Elmer, Waltham, MA, USA) was used to evaluate mineral contents of $\mathrm{Ca}, \mathrm{Cu}, \mathrm{Fe}, \mathrm{K}, \mathrm{Mg}, \mathrm{Mn}, \mathrm{Na}, \mathrm{P}, \mathrm{S}$ and $\mathrm{Zn}$. The mineral contents were calculated as absolute concentration $\mathrm{mg} / \mathrm{kg}$. Standards used in the analysis were atomic spectrometry standards from Perkin-Elmer, SPEX, AccuStandard and Merck. Calibration of the ICP-OES instrument was done by using a mixed multicomponent standard at three concentrations within the factor of 50 and calibration was maintained with independent standards. The detection limit used was three times the standard deviation based on multiple determination of the blanks treated as the sample, were blanks were treated identically and together with the samples.

\subsection{Statistical Analyses}

Analysis of variance (ANOVA), general linear model analyses (GLM), Pearson correlation analyses and principle component analysis (PCA) were carried out using the statistical analysis system (SAS; SAS Institute, Cary, NC, USA, 1985). Mean values were calculated following the ANOVA and GLM analyses, separating the means by the use of Tukey post-hoc test at $p<0.05$. Percentage of explanation (obtained from the coefficient of determination $-\mathrm{R}^{2}$ ) of different sources (cultivar, location and their combinations) on content of total and various types of minerals were calculated using a simple linear regression analysis, following the procedure described in previous investigations [14,40-42]. Values of genotypes, localities, years and groups were ranked based on mean minerals content following in accordance with procedures reported previously [41]. By linear regression analysis, an independent variable can be used to predict the value of a dependent variable, and the $R^{2}$ value of a linear regression analysis predicts how well a feature (independent variable) can explain a target (dependent variable) [43]. Thus, an $R^{2}$ close to 1 means that the proportion is high that the independent variable explains the dependent variable 
(https:/ / www.colby.edu/biology/BI17x/regression.html, access date 18 December 2020), which makes it possible to select the sources that are of highest importance to determine different traits [43]. Principal component analyses (PCA) was carried out for all minerals across all locations and years for the 12 genotypes in common for all localites to compare the effects of genotype, the locality and the year on minerals composition. Furthermore, PCA was carried out separately for all genotypes across years for each of the localities, to evaluate effects of genotypes and years on mineral composition at various locations and options for local adaptation.

\subsection{Calculation of Nutritional Yield and Nutrient Density}

Nutritional yield (NY) and nutrient density (ND) were calculated according to MorreiraAscarrunz et al. [14], using equations below:

$$
N Y=\frac{Y \times M C}{D R I \times 365}
$$

where $Y=$ Yield $\left(\mathrm{kg} \mathrm{ha}^{-1}\right), M C=$ mineral content of a specific element $\left(\mathrm{mg} \mathrm{kg}^{-1}\right), D R I=$ Daily Recommended Intake of a specific element, $365=$ number of days in a year.

$$
N D=\frac{1000 \times D R I}{M C}
$$

where $D R I=$ Daily Recommended Intake of a specific element, $M C=$ mineral content of a specific element $\left(\mathrm{mg} \mathrm{kg}^{-1}\right)$.

Thus, the nutritional yield is describing the number of adults that can fulfill $100 \%$ of their daily recommended intake needs with one hectare of cereals per year. For nutritional yield calculations on hulled genotypes such as the ancient wheat, oats and barley a yield correction of $75 \%$ was used following the methodology of Morreira-Ascarrunz et al. [14]. Values used for $\mathrm{Fe}\left(12 \mathrm{mg} \mathrm{day}^{-1}\right)$ and $\mathrm{Zn}\left(8 \mathrm{mg} \mathrm{day}^{-1}\right)$ daily recommended intake (DRI) follows the one calculated in Morreira-Ascarrunz et al. [14] and are based on an intake sufficient for the needs of $97 \%$ of individuals in an age- and sex-specific group, averaged among adult men and women.

\section{Results}

\subsection{Variation of Mineral Contents in the Material}

Generally a large variation was found in minerals content in the evaluated spring cereals (Table S1). Mean values over three years varied $1.5(\mathrm{Mg})$ - to $15(\mathrm{Mn})$-fold among genotypes and locations; Zn 29.5-56.5 mg kg-1, S 1233-2357 $\mathrm{mg} \mathrm{kg}^{-1}$, P $3551-6027 \mathrm{mg} \mathrm{kg}^{-1}$, Na 9.7-55.5 mg kg ${ }^{-1}$, Mn 4.2-60.5 mg kg ${ }^{-1}, \mathrm{Mg} 1042-1732 \mathrm{mg} \mathrm{kg}^{-1}, \mathrm{~K} 3169-4639 \mathrm{mg} \mathrm{kg}^{-1}$, Fe 27.1-64.9 $\mathrm{mg} \mathrm{kg}^{-1}, \mathrm{Cu} 3.45-8.17 \mathrm{mg} \mathrm{kg}^{-1}$ and Ca $292-920 \mathrm{mg} \mathrm{kg}^{-1}$. General linear model analyses for the 12 genotypes in common for all localities, showed significant impact of genotype $(\mathrm{Ge})$, cultivation location $(\mathrm{C})$, cultivation year $(\mathrm{Y})$ and $\mathrm{C} \times \mathrm{Y}$ interactions on content of practically all minerals while the effects of $\mathrm{Ge} \times \mathrm{L}$ and $\mathrm{Ge} \times \mathrm{Y}$ interactions were limited (Table 3). Anova analyses on the seven genotype groups (Gr) showed a significant impact of all sources $(\mathrm{Gr}, \mathrm{L}, \mathrm{Y})$ and their interactions $(\mathrm{Gr} \times \mathrm{L}, \mathrm{Gr} \times \mathrm{Y}, \mathrm{L} \times \mathrm{Y})$ on in practical content of all minerals.

$R$ square values used to explain the percentage of explanation for the different minerals, showed for most of the minerals a higher degree of explanation for the genotype/genotype group analyzed as compared to the location and year used for cultivation. However, for content of $\mathrm{Zn}, \mathrm{Mn}$ and $\mathrm{Cu}$, cultivation locality turned out to have the highest degree of explanation and also for $\mathrm{Fe}$, the locality contributed to a high degree of explanation (Table 4). Furthermore, cultivation year showed a high impact on the degree of explanation for several of the analyzed minerals (e.g., $\mathrm{Zn}, \mathrm{K}, \mathrm{Cu}, \mathrm{Ca}$; Table 4). 
Table 3. Mean squares from the general linear model analyses (GLM) for 12 genotypes and analyses of variance (ANOVA) for seven genotype groups indicating impact on minerals content from genotypes (Ge), Genotype groups (Gr), localities (L), years $(\mathrm{Y})$ and their interactions.

\begin{tabular}{|c|c|c|c|c|c|c|c|c|c|c|c|}
\hline Source & Df & $\begin{array}{c}\mathrm{Zn} \\
\left(10^{3}\right)\end{array}$ & $\begin{array}{c}S \\
\left(10^{5}\right)\end{array}$ & $\begin{array}{c}P \\
\left(10^{6}\right)\end{array}$ & $\begin{array}{c}\mathrm{Na} \\
\left(10^{3}\right)\end{array}$ & $\begin{array}{c}\mathrm{Mn} \\
\left(10^{3}\right)\end{array}$ & $\begin{array}{c}\mathrm{Mg} \\
\left(10^{5}\right)\end{array}$ & $\begin{array}{c}K \\
\left(10^{6}\right)\end{array}$ & $\begin{array}{c}\mathrm{Fe} \\
\left(10^{2}\right)\end{array}$ & $\mathrm{Cu}$ & $\begin{array}{c}\mathrm{Ca} \\
\left(10^{5}\right)\end{array}$ \\
\hline \multicolumn{12}{|c|}{12 genotypes over four locations and three years } \\
\hline Genotype & 11 & $0.32^{* * *}$ & $4.57^{* * *}$ & $2.57^{* * *}$ & $2.32 * * *$ & $1.07^{* * *}$ & $1.80^{* * *}$ & $1.12^{* * *}$ & $2.13^{* * *}$ & $2.34^{* * *}$ & $1.47^{* * *}$ \\
\hline Locality & 3 & $1.18^{* * *}$ & $4.82^{* * *}$ & $1.19^{* * *}$ & $1.09^{* * *}$ & $4.16^{* * *}$ & $1.20^{* * *}$ & 0.06 & $6.72^{* * *}$ & $22.7^{* * *}$ & $0.28^{* * *}$ \\
\hline Year & 2 & $0.08^{* * *}$ & $2.32 *$ & 0.10 & $1.92^{* * *}$ & $0.34^{* * *}$ & $0.70^{* * *}$ & $4.26^{* * *}$ & $1.57^{* * *}$ & $21.7^{* * *}$ & $2.47^{* * * *}$ \\
\hline $\mathrm{Ge}^{*} \mathrm{~L}$ & 33 & 0.03 & 0.20 & 0.13 & 0.21 & $0.10^{* * *}$ & $0.15^{*}$ & 0.08 & 0.54 & 0.36 & 0.03 \\
\hline $\mathrm{Ge}^{*} \mathrm{Y}$ & 21 & 0.03 & 0.23 & $0.21 * *$ & $0.36^{* * *}$ & $0.07 *$ & 0.13 & $0.10 *$ & 0.60 & 0.40 & $0.12^{* * * *}$ \\
\hline$L^{*} Y$ & 6 & $0.14^{* * *}$ & $2.03^{* * *}$ & $0.66^{* * *}$ & $0.82^{* * *}$ & $0.17^{* * *}$ & $0.31^{* * *}$ & $0.31^{* * *}$ & $3.12^{* * *}$ & $4.01^{* * *}$ & $0.07^{* * *}$ \\
\hline Error & 182 & 0.02 & 0.17 & 0.09 & 0.14 & 0.03 & 0.08 & 0.05 & 0.56 & 0.24 & 0.01 \\
\hline \multicolumn{12}{|c|}{7 genotype groups over four locations and three years } \\
\hline Group & 6 & $0.79 * * *$ & $31.4^{* * *}$ & $15.1^{* * *}$ & $5.33^{* * *}$ & $4.84^{* * *}$ & $8.82 * * *$ & $1.68^{* * *}$ & $10.3^{* * *}$ & $6.98^{* * *}$ & $6.26^{* * *}$ \\
\hline Locality & 3 & $1.93^{* * *}$ & $11.1^{* * *}$ & $3.20^{* * *}$ & $2.87^{* * *}$ & $9.84^{* * *}$ & $2.86^{* * *}$ & 0.10 & $9.28^{* * *}$ & $50.3^{* * *}$ & $0.85^{* * * *}$ \\
\hline Year & 2 & $2.33^{* * *}$ & $4.65^{* * *}$ & $0.73^{* * *}$ & $3.87^{* * *}$ & $1.25^{* * *}$ & $1.17^{* * *}$ & $6.44^{* * *}$ & $10.2^{* * *}$ & $54.7^{* * *}$ & $3.81^{* * *}$ \\
\hline $\mathrm{Gr}^{*} \mathrm{~L}$ & 18 & $0.09 * * *$ & 0.28 & 0.15 & $0.34^{* * *}$ & $0.35^{* * *}$ & $0.41^{* * *}$ & $0.34^{* * *}$ & $1.23^{* * *}$ & $0.93^{* * *}$ & $0.10^{* * * *}$ \\
\hline $\mathrm{Gr}^{*} \mathrm{Y}$ & 12 & $0.06^{* * *}$ & $0.54^{* * *}$ & $0.48^{* * *}$ & $1.14^{* * *}$ & $0.15^{* * *}$ & $0.33^{* * *}$ & $0.24^{* * *}$ & $1.61^{* * *}$ & $1.29^{* * *}$ & $0.59^{* * *}$ \\
\hline$L^{*} Y$ & 6 & $0.21^{* * *}$ & $5.24^{* * *}$ & $1.28^{* * *}$ & $1.06^{* * *}$ & $0.44^{* * *}$ & $0.49^{* * *}$ & $0.52^{* * *}$ & $5.94^{* * *}$ & $8.66^{* * *}$ & $0.26^{* * *}$ \\
\hline Error & 84 & 0.03 & 0.18 & 0.13 & 0.12 & 0.03 & 0.09 & 0.05 & 0.51 & 0.44 & 0.03 \\
\hline
\end{tabular}

$* * * * * * *$ Significant at $p<0.05,0.01$ and 0.005 .

Table 4. Percentage of explanation (obtained through the coefficient of determination $\left[\mathrm{R}^{2}\right]$ from simple linear regression analyses) of 12 genotypes across four locations and three years, and 7 genotype groups across four locations and three years, on amount of various minerals.

\begin{tabular}{ccccccccccc}
\hline Source & $\mathbf{Z n}$ & $\mathbf{S}$ & $\mathbf{P}$ & $\mathbf{N a}$ & $\mathbf{M n}$ & $\mathbf{M g}$ & $\mathbf{K}$ & $\mathbf{F e}$ & $\mathbf{C u}$ & $\mathbf{C a}$ \\
\hline Genotype & 25.1 & 42.3 & 50.6 & 28.2 & 29.8 & 43.8 & 36.8 & 14.0 & 17.0 & 55.9 \\
Locality & 29.3 & 15.0 & 8.58 & 6.20 & 39.1 & 8.32 & 0.94 & 10.2 & 25.9 & 3.86 \\
$\quad$ Year & 9.32 & 1.90 & 0.47 & 7.33 & 2.52 & 1.20 & 19.2 & 2.18 & 22.0 & 15.1 \\
\hline Group & 5.16 & 53.0 & 59.6 & 19.2 & 35.6 & 51.1 & 18.7 & 6.24 & 6.53 & 54.5 \\
Locality & 23.2 & 9.45 & 6.19 & 5.74 & 37.5 & 7.19 & 0.25 & 8.70 & 29.0 & 3.54 \\
Year & 16.1 & 3.14 & 0.46 & 7.11 & 2.44 & 1.64 & 22.9 & 5.79 & 19.0 & 11.1 \\
\hline
\end{tabular}

\subsection{Minerals Variation by Genotype, Cultivation Location, Cultivation Year and Genotype Group}

The comparison of 12 spring cereal genotypes over the four environments and years, showed clear differences in mineral content and composition among the genotypes (Table 5). High level of S, P, Mg and Fe was found in black oats cultivar Engelbrekt, high level of $\mathrm{Zn}$ was found in Emmer Gotland. The spring barley variety Ingrid showed low levels of $\mathrm{Zn}, \mathrm{S}, \mathrm{P}, \mathrm{Mn}, \mathrm{Mg}$, K, Fe Cu and Ca. Among the localities, high levels of $\mathrm{Zn}, \mathrm{S}$, $\mathrm{Fe}$ and $\mathrm{Cu}$ were found in cereals grown at Ekhaga, while low levels of $\mathrm{Zn}, \mathrm{S}, \mathrm{Mg}$, Fe and $\mathrm{Cu}$ were found in cereals grown in Alnarp (Table 5). High levels of $\mathrm{Zn}, \mathrm{Na}, \mathrm{K}$ and $\mathrm{Ca}$ were found in the cereals when grown 2013, while high levels of $\mathrm{Mn}, \mathrm{K}$ and $\mathrm{Cu}$ were found for those grown 2011 (Table 5). Sorting the spring cereals investigated into different groups, showed ancient wheat such as spelt and emmer to contain high levels of $\mathrm{Zn}, \mathrm{Mg}$ and $\mathrm{Cu}$, while oats showed high levels of S, P, Mn and Fe. Low levels of most of the minerals were found in barley (Table 5). 
Table 5. Mean values of content of minerals $\left(\mathrm{mg} \mathrm{kg}^{-1}\right)$ in twelve genotypes over four localities and three cultivation years.

\begin{tabular}{|c|c|c|c|c|c|c|c|c|c|c|}
\hline Source & $\operatorname{Zn}\left(10^{1}\right)$ & $S\left(10^{3}\right)$ & $P\left(10^{3}\right)$ & $\mathrm{Na}\left(10^{1}\right)$ & $\operatorname{Mn}\left(10^{1}\right)$ & $\operatorname{Mg}\left(10^{3}\right)$ & $K\left(10^{3}\right)$ & $\mathrm{Fe}\left(10^{1}\right)$ & $\mathrm{Cu}$ & Ca $\left(10^{2}\right)$ \\
\hline \multicolumn{11}{|l|}{ Genotypes } \\
\hline Diamant brun & $4.60^{\mathrm{a}, \mathrm{b}}$ & $1.57^{b, c, d, e}$ & $4.36^{\mathrm{c}, \mathrm{d}}$ & $1.91^{b}$ & $3.41^{a, b}$ & $1.30^{\mathrm{c}, \mathrm{d}}$ & $3.60^{c}$ & $4.65^{\mathrm{a}}$ & $5.32^{a, b, c, d}$ & $5.57^{\mathrm{d}}$ \\
\hline Ella & $4.01^{b, c}$ & $1.50^{\mathrm{d}, \mathrm{e}}$ & $4.27^{\mathrm{d}}$ & $2.11^{b}$ & $3.01^{b, c}$ & $1.30^{\mathrm{c}, \mathrm{d}}$ & $3.69^{c}$ & $4.08^{\mathrm{a}, \mathrm{b}}$ & $5.45^{\mathrm{a}, \mathrm{b}, \mathrm{c}, \mathrm{d}}$ & $4.95^{\mathrm{e}, \mathrm{f}}$ \\
\hline Emmer Gotland & $4.82^{\mathrm{a}}$ & $1.61^{b, c, d}$ & $5.00^{a, b}$ & $2.28^{b}$ & $3.09^{b, c}$ & $1.46^{\mathrm{a}, \mathrm{b}}$ & $4.15^{\mathrm{a}, \mathrm{b}}$ & $4.38^{\mathrm{a}}$ & $6.13^{a, b}$ & $4.01^{\mathrm{g}}$ \\
\hline Engelbrekt & $3.93^{b, c}$ & $1.95^{\mathrm{a}}$ & $5.41^{\mathrm{a}}$ & $2.82^{b}$ & $3.78^{a, b}$ & $1.47^{\mathrm{a}}$ & $3.65^{c}$ & $4.89^{\mathrm{a}}$ & $5.23^{b, c, d}$ & $6.16^{\mathrm{c}}$ \\
\hline Hulless 6row barley & $3.79^{c}$ & $1.53^{\mathrm{c}, \mathrm{d}, \mathrm{e}}$ & $4.57^{b, c, d}$ & $5.69^{a}$ & $1.55^{\mathrm{e}, \mathrm{f}}$ & $1.30^{b, c}$ & $4.22^{\mathrm{a}, \mathrm{b}}$ & $4.32^{\mathrm{a}, \mathrm{b}}$ & $4.86^{\mathrm{c}, \mathrm{d}}$ & $5.48^{\mathrm{d}}$ \\
\hline Hulless 2row barley & $3.79^{c}$ & $1.60^{b, c, d, e}$ & $5.03^{a, b}$ & $5.96^{\mathrm{a}}$ & $1.64^{\mathrm{d}, \mathrm{e}}$ & $1.36^{\mathrm{a}, \mathrm{b}, \mathrm{c}}$ & $4.34^{\mathrm{a}}$ & $4.61^{\mathrm{a}}$ & $5.58^{a, b, c}$ & $5.59^{\mathrm{d}}$ \\
\hline Ingrid & $2.70^{d}$ & $1.34^{\mathrm{e}}$ & $3.70^{\mathrm{e}}$ & $3.26^{b}$ & $0.80^{\mathrm{f}}$ & $1.08^{\mathrm{e}}$ & $3.52^{c}$ & $3.09^{b}$ & $4.46^{\mathrm{d}}$ & $3.22 \mathrm{~g}$ \\
\hline Jusso & $4.17^{\mathrm{a}, \mathrm{b}, \mathrm{c}}$ & $1.50^{\mathrm{d}, \mathrm{e}}$ & $4.22 \mathrm{~d}, \mathrm{e}$ & $2.00^{b}$ & $2.40^{c, d}$ & $1.15^{\mathrm{d}, \mathrm{e}}$ & $4.43^{\mathrm{a}}$ & $4.33^{\mathrm{a}, \mathrm{b}}$ & $5.38^{\mathrm{a}, \mathrm{b}, \mathrm{c}, \mathrm{d}}$ & $4.69^{\mathrm{f}}$ \\
\hline Spelt wheat Gotland & $4.41^{\mathrm{a}, \mathrm{b}, \mathrm{c}}$ & $1.80^{\mathrm{a}, \mathrm{b}, \mathrm{c}}$ & $4.90^{\mathrm{a}, \mathrm{b}}$ & $2.18^{b}$ & $2.86^{a, b}$ & $1.47^{\mathrm{a}}$ & $3.72^{b, c}$ & $4.27^{\mathrm{a}}$ & $6.76^{a}$ & $3.34^{\mathrm{g}}$ \\
\hline Virma & $3.90^{b, c}$ & $2.00^{\mathrm{a}}$ & $5.12^{\mathrm{a}, \mathrm{b}}$ & $1.88^{\mathrm{b}}$ & $4.08^{\mathrm{a}}$ & $1.41^{\mathrm{a}, \mathrm{b}, \mathrm{c}}$ & $3.89^{b, c}$ & $4.55^{\mathrm{a}}$ & $4.97^{\mathrm{c}, \mathrm{d}}$ & $6.62^{b}$ \\
\hline Öland & $4.15^{\mathrm{a}, \mathrm{b}, \mathrm{c}}$ & $1.60^{b, c, d, e}$ & $4.68^{b, c, d}$ & $1.54^{\mathrm{b}}$ & $3.16^{b, c}$ & $1.40^{\mathrm{a}, \mathrm{b}, \mathrm{c}}$ & $3.70^{\mathrm{c}}$ & $4.92^{\mathrm{a}}$ & $5.27^{\mathrm{a}, \mathrm{b}, \mathrm{c}, \mathrm{d}}$ & $5.19^{\mathrm{d}, \mathrm{e}}$ \\
\hline \multicolumn{11}{|l|}{ Localities } \\
\hline Ekhaga & $4.88^{\mathrm{a}}$ & $1.76^{\mathrm{a}}$ & $4.68^{b}$ & $3.14^{\mathrm{a}}$ & $3.41^{b}$ & $1.37^{\mathrm{a}}$ & $3.87^{\mathrm{a}}$ & $5.01^{\mathrm{a}}$ & $6.41^{\mathrm{a}}$ & $5.18^{b}$ \\
\hline Krusenberg & $3.91^{b}$ & $1.60^{b, c}$ & $4.42^{c}$ & $1.82^{b}$ & $4.13^{\mathrm{a}}$ & $1.29^{b}$ & $3.84^{\mathrm{a}}$ & $4.27^{b}$ & $4.89^{b, c}$ & $4.71^{\mathrm{c}}$ \\
\hline Alnarp & $3.23^{c}$ & $1.49^{\mathrm{c}}$ & $4.64^{b, c}$ & $3.05^{\mathrm{a}}$ & $2.25^{c}$ & $1.28^{\mathrm{b}}$ & $3.94^{\mathrm{a}}$ & $4.06^{\mathrm{b}}$ & $4.56^{\mathrm{c}}$ & $5.24^{\mathrm{b}}$ \\
\hline \multicolumn{11}{|l|}{ Years } \\
\hline 2011 & $3.79^{b}$ & $1.60^{\mathrm{a}}$ & $4.68^{a}$ & $2.26^{b}$ & $3.18^{a}$ & $1.31^{\mathrm{a}}$ & $4.11^{\mathrm{a}}$ & $4.20^{\mathrm{a}}$ & $4.53^{b}$ & $5.17^{b}$ \\
\hline 2012 & $3.76^{b}$ & $1.64^{\mathrm{a}}$ & $4.71^{\mathrm{a}}$ & $2.63^{b}$ & $2.61^{b}$ & $1.35^{\mathrm{a}}$ & $3.55^{b}$ & $4.51^{\mathrm{a}}$ & $5.83^{\mathrm{a}}$ & $4.50^{\mathrm{c}}$ \\
\hline 2013 & $4.56^{\mathrm{a}}$ & $1.70^{\mathrm{a}}$ & $4.63^{\mathrm{a}}$ & $3.80^{\mathrm{a}}$ & $2.62^{b}$ & $1.36^{\mathrm{a}}$ & $4.08^{a}$ & $4.49^{a}$ & $5.63^{a}$ & $6.05^{\mathrm{a}}$ \\
\hline \multicolumn{11}{|l|}{ Groups } \\
\hline Rye & $4.17^{\mathrm{a}, \mathrm{b}}$ & $1.50^{b, c, d}$ & $4.22^{\mathrm{d}, \mathrm{e}}$ & $2.00^{b, c}$ & $2.40^{b, c}$ & $1.15^{\mathrm{c}}$ & $4.43^{\mathrm{a}}$ & $4.33^{a, b}$ & $5.38^{a, b}$ & $4.69^{b, c}$ \\
\hline Oats & $3.98^{b}$ & $2.03^{a}$ & $5.40^{\mathrm{a}}$ & $2.16^{\mathrm{c}}$ & $3.84^{\mathrm{a}}$ & $1.49^{\mathrm{a}}$ & $3.85^{c, d}$ & $4.88^{\mathrm{a}}$ & $5.05^{b}$ & $6.69^{a}$ \\
\hline Wheat & $3.84^{b}$ & $1.50^{\mathrm{c}}$ & $4.20^{\mathrm{d}, \mathrm{e}}$ & $2.20^{\mathrm{c}}$ & $2.89^{b}$ & $1.28^{b}$ & $3.80^{c, d}$ & $4.02^{b, c}$ & $5.10^{b}$ & $4.94^{\mathrm{b}}$ \\
\hline Ancient wheat & $4.68^{\mathrm{a}}$ & $1.72^{\mathrm{b}}$ & $5.04^{\mathrm{b}}$ & $2.20^{\mathrm{c}}$ & $3.04^{a, b}$ & $1.49^{\mathrm{a}}$ & $3.98^{b, c}$ & $4.34^{\mathrm{a}, \mathrm{b}}$ & $6.36^{\mathrm{a}}$ & $3.74^{\mathrm{c}, \mathrm{d}}$ \\
\hline Naked barley & $3.79^{b}$ & $1.57^{b, c}$ & $4.79 \mathrm{~b}, \mathrm{c}$ & $5.82^{\mathrm{a}}$ & $1.59^{c, d}$ & $1.33^{b}$ & $4.28^{a, b}$ & $4.46^{\mathrm{a}, \mathrm{b}}$ & $5.21^{b}$ & $5.54^{\mathrm{b}}$ \\
\hline Barley & $3.09^{c}$ & $1.34^{\mathrm{d}}$ & $3.98^{\mathrm{e}}$ & $3.50^{b}$ & $1.01^{\mathrm{d}}$ & $1.12^{\mathrm{c}}$ & $3.67^{\mathrm{d}}$ & $3.54^{\mathrm{c}}$ & $4.82^{b}$ & $3.54^{\mathrm{d}}$ \\
\hline Landrace wheat & $4.07^{\mathrm{a}, \mathrm{b}}$ & $1.57^{b, c}$ & $4.45^{\mathrm{c}, \mathrm{d}}$ & $1.98^{c}$ & $3.40^{a, b}$ & $1.32^{b}$ & $3.89^{c, d}$ & $4.38^{\mathrm{a}, \mathrm{b}}$ & $5.35^{\mathrm{b}}$ & $4.97^{b}$ \\
\hline
\end{tabular}

Numbers followed by the same letters within a column for each of the sources do not differ significantly by the use of Tukey post-hoc test at $p<0.05$. 


\subsection{Combined Impact of Genotype/Genotype Group, Cultivation Location and Year on} Minerals Content

The score plot from the principal component analyses (PCA) of genotypes, locations and years (Figure S1) and genotype groups, locations and years (Figure 1a), indicated a co-variation of the minerals over the different samples, with positive values on the first principal component (PC1) for all the evaluated minerals, also verified by highly significant Pearson correlation coefficients between most of the minerals (Table S2).

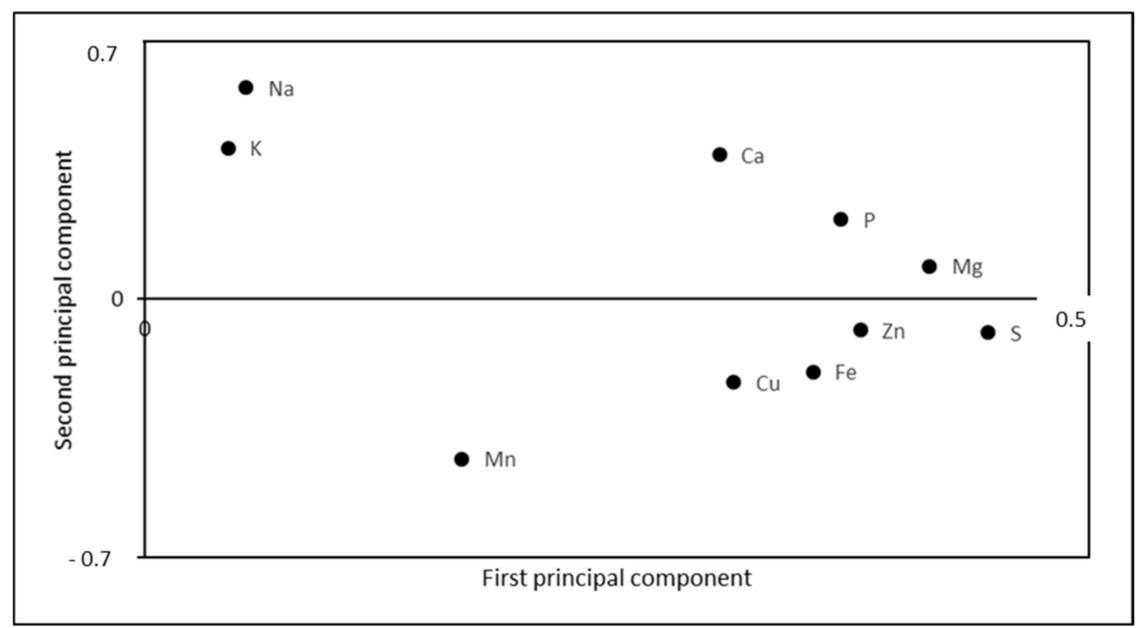

(a)

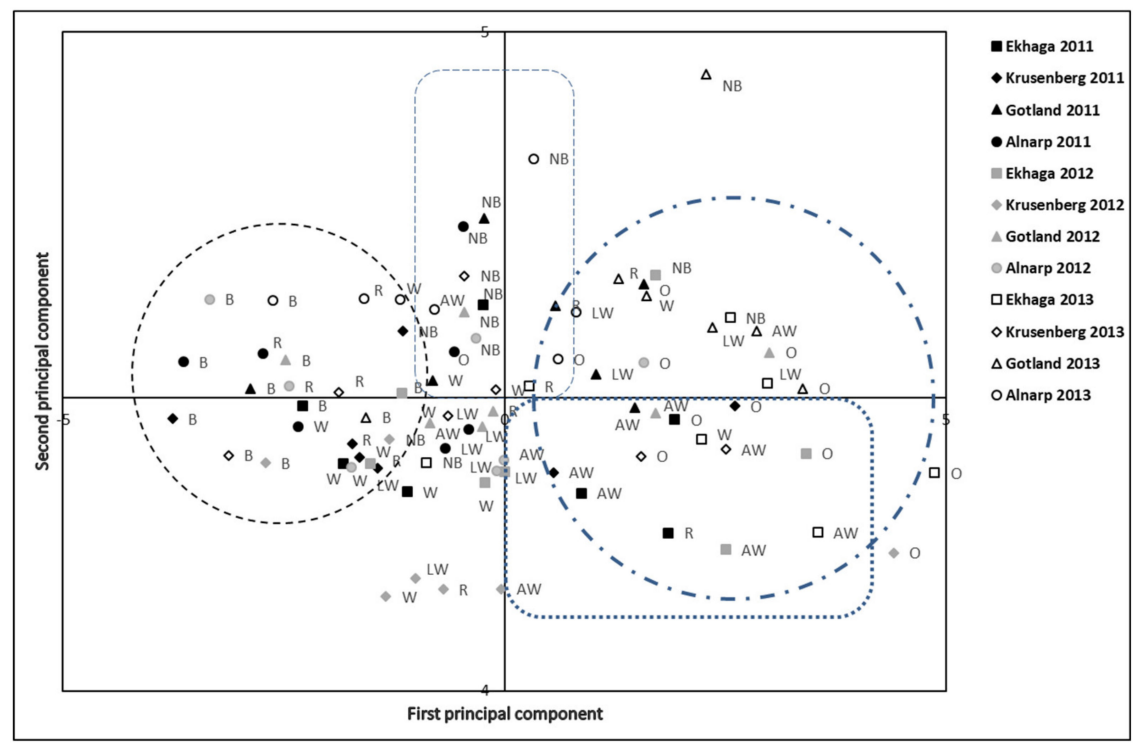

(b)

Figure 1. Score (a) and loading (b) plot from principal component analysis of mineral content in spring cereal genotype groups (Rye-R, Oats-O, Wheat-W, Ancient wheat-AW, Naked barley-NB, Barley-B, Landrace wheat-LW) grown at different localities (Ekhaga, Krusenberg, Gotland, Alnarp) during different years (2011, 2012, 2013). First principal component explained 38.4\% of the variation and the second principal component explained $17.7 \%$ of the variation. Black dotted circle to the left appoint the majority of the Barley (B) group samples, black dotted rectangle in the top indicate the majority of the Naked barley (NB) group samples, blue dotted circle to the right mark majority of the Oat $(\mathrm{O})$ group samples, and low dotted blue rectangle mark the majority of the Ancient wheat (AW) group samples. 
The loading plot of the PCA of the twelve spring cereal samples differentiated a spread of the samples based on cultivation locality along PC1, with the majority of the Ekhaga samples showing positive PC1 values, thereby indicating high mineral levels and the majority of the Alnarp samples with negative PC1 values indicating low mineral levels (Figure S1). However, the spring barley cultivar Ingrid was consistently over all cultivation locations found with low PCA2 values indicating low levels of minerals. For the rest of the 12 genotypes, no consistent pattern could be differentiated with the PCA explaining their variation in minerals content and composition (Supplementary Figure S1).

The loading plot of the PCA of the seven genotype groups clearly differentiatedthe different genotype groups. Thus, the majority (11 out of 12) of the oat group samples were found with positive PC1, only the sample from Alnarp 2011 showed a negative PC1 value, thereby indicating a general high mineral content in the oats samples evaluated in the present study (Figure 1b). Furthermore, the majority of the ancient wheat group samples (9 out of 12) were found with positive PC1 values and negative PC2 values indicating generally high Fe and $\mathrm{Zn}$ values, although two of the Alnarp samples (2011 and 2013) were found with negative PC1values (Figure 1b). The barley genotype group samples were generally found (12 out of 12 samples) with low PC1 values, indicating a lower minerals content than what was found in the rest of the samples evaluated here (Figure 1b). The majority of the naked barley group samples were found gathered along the PC2 with positive values (9 out of 12), indicating high levels of $\mathrm{Na}$ and $\mathrm{K}$, with only two samples (Alnarp 2011 and Gotland 2012) showing negative PC2 values (Figure 1b). The samples of the rest of the genotype groups (rye, wheat and wheat landraces showed a larger spread of PC values in the loading plot (Figure 1b).

\subsection{Local Adaptation of the Genotypes}

PCA analyses separately on samples from a specific cultivation location, verified for each of the locations a similar score plot as described above for the full material (Figure 1a). Thus, for each of the locations, all minerals clustered with positive PC1 values, indicating a co-variation of the minerals in samples for each location. Thus, genotypes with consistently positive $\mathrm{PC} 1$ values in a specific location, over the three years of study, should be considered as having a good chance to produce high mineral content at that location independently of yearly climate fluctuations, and such genotypes are presented in Table 6. From the present study, it was clearly shown that oats and ancient wheat was outstanding as high mineral genotypes groups across the four cultivation locations (Table 6). Among the oats, some genotypes as Engelbrekt and Virma, resulted in positive PC1 values, indicating high minerals content, across all four locations and in all evaluted years (Table 6). Such genotypes are specifically interesting for breeding and produce across different local environments across Sweden. Some of the genotypes were only tested in some of the locations (1-3) due to an expectation of a local adaptation to that locality of the genotype. Several such oat genotypes were found to perform well in the locality/ies they were tested (e.g., Bambu, Orion, Sisu, Sol etc.; Table 6), and these genotypes might be of interest to test in a broader set of environments, to verify their possible local adaptation. For landrace wheat, wheat and naked barley, a clear local adaptation was seen in the present material. Thus, positive PC1 values was obtained for Diamant brun (wheat), Hulless 2row barley (naked barley) and Öland (landrace wheat) was obtained in Alnarp, which was not seen in the other localities (Table 6), despite these genotypes belonged to the 12 grown in all four localities. These findings might indicate a local adaptation of these genotypes from the south of Sweden to cultivation environments similar to the one in Alnarp. 
Table 6. PC1 values from each cultivation location for genotypes with positive PC1 values in all years for all ten minerals evaluated and for four $(\mathrm{Zn}, \mathrm{Fe}, \mathrm{Mg}$ and $\mathrm{Cu}$ ) minerals of specific nutritional importance [14].

\begin{tabular}{|c|c|c|c|c|c|c|c|}
\hline \multirow{2}{*}{ Location and Genotype } & \multirow{2}{*}{ Genotype Group } & \multicolumn{3}{|c|}{ All Ten Minerals } & \multicolumn{3}{|c|}{ Four Selected Minerals } \\
\hline & & 2011 & 2012 & 2013 & 2011 & 2012 & 2013 \\
\hline \multicolumn{8}{|l|}{ Ekhaga } \\
\hline Bambu & Oat & 1.67 & 3.71 & 3.30 & & & \\
\hline Emmer Gotland & Ancient & & & & 0.05 & 2.60 & 1.93 \\
\hline Engelbrekt & Oat & 0.10 & 2.80 & 1.76 & & & \\
\hline Orion & Oat & 2.83 & 4.28 & 3.01 & 0.85 & 2.43 & 2.18 \\
\hline Sisu & Oat & 0.14 & 2.14 & 2.00 & & & \\
\hline Sol & Oat & 0.31 & 3.64 & 0.79 & & & \\
\hline Spelt Gotland & Ancient & 0.06 & 1.11 & $x$ & 0.03 & 2.38 & $x$ \\
\hline Virma & Oat & 1.07 & 3.34 & 2.77 & & & \\
\hline \multicolumn{8}{|l|}{ Krusenberg } \\
\hline Emmer Gotland & Ancient & & & & 1.56 & 1.43 & 0.66 \\
\hline Engelbrekt & Oat & 2.83 & 1.14 & 2.22 & 1.71 & 0.61 & 2.29 \\
\hline Extra klock & Oat & 2.16 & 2.15 & 3.32 & 0.17 & 0.49 & 3.09 \\
\hline Orion & Oat & 3.32 & 2.05 & 5.13 & 1.57 & 1.12 & 4.15 \\
\hline Seger & Oat & 2.91 & 3.54 & 5.22 & 1.22 & 1.86 & 393 \\
\hline Sol & Oat & 2.51 & 1.93 & 4.21 & 0.70 & 0.80 & 3.04 \\
\hline Spelt Gotland & Ancient & & & & 0.30 & 2.36 & 1.34 \\
\hline Virma & Oat & 2.41 & 0.36 & 2.34 & & & \\
\hline \multicolumn{8}{|l|}{ Gotland } \\
\hline Argus & Oat & 0.51 & 3.36 & $x$ & & & \\
\hline Blenda & Oat & 0.85 & 1.26 & 1.72 & & & \\
\hline Emmer Gotland & Ancient & 1.29 & 1.07 & 1.28 & 1.62 & 0.62 & 2.45 \\
\hline Engelbrekt & Oat & 0.61 & 2.28 & 0.83 & & & \\
\hline Hulless oats & Oat & 0.53 & 1.44 & $X$ & & & \\
\hline Orion & Oat & 1.52 & 4.20 & 1.68 & & & \\
\hline Spelt wheat Gotland & Ancient & 1.02 & 0.73 & $X$ & 1.61 & 1.29 & $x$ \\
\hline Spelt wheat Gotland d & Ancient & & & & 0.08 & 1.21 & 3.52 \\
\hline Sommarhavre & Oat & 2.45 & 3.08 & 2.39 & 0.02 & 0.86 & 2.91 \\
\hline Ur Gotland & Oat & 2.98 & 4.17 & 2.50 & 0.31 & 2.07 & 2.28 \\
\hline Virma & Oat & 1.13 & 0.86 & 1.69 & & & \\
\hline \multicolumn{8}{|l|}{ Alnarp } \\
\hline Diamant brun & Wheat & 0.72 & 1.72 & 0.88 & 0.81 & 1.99 & 1.12 \\
\hline Engelbrekt & Oat & 0.67 & 3.75 & $X$ & & & \\
\hline Emmer Gotland & Ancient & & & & 0.96 & 1.93 & 0.62 \\
\hline Hulless 2row barley & Naked barley & 0.20 & 0.92 & 0.65 & 0.84 & 1.08 & 1.24 \\
\hline Klock & Oat & 1.51 & 3.81 & 2.09 & & & \\
\hline Palu & Oat & 1.07 & 3.32 & 1.87 & & & \\
\hline Seger & Oat & 1.33 & 4.64 & $x$ & & & \\
\hline Spelt wheat Gotland & Ancient & 0.70 & 1.52 & $X$ & 1.35 & 2.41 & $x$ \\
\hline Osmo & Oat & 2.21 & 5.57 & 2.62 & 0.11 & 3.32 & 1.20 \\
\hline Virma & Oat & 0.67 & 1.95 & 1.51 & & & \\
\hline Öland & Landrace wheat & 0.61 & 1.52 & 1.93 & 0.81 & 1.71 & 2.18 \\
\hline
\end{tabular}

$\mathrm{X}=$ mineral value lacking 2014 .

PCA for each locality on four selected minerals $(\mathrm{Zn}, \mathrm{Fe}, \mathrm{Mg}$ and $\mathrm{Cu}$ ) resulted in a score plot with positive PC1 for all minerals (not shown), and depicted clearly the ancient wheats across all four locations with positive PC1, thereby whith high levels of the selected four minerals (Table 6). Furthermore, several oats genotypes in particular when grown in Krusenberg, depicting some local adaptation, and Diamant brun (wheat), Hulless 2row barley (naked barley) and Öland (landrace wheat) when grown in Alnarp, showed positive PC1 values (Table 6) indicating high levels of the minerals of choice, and local adaptation. 


\subsection{Nutritional Yield and Nutrient Density}

Mean nutritional $\mathrm{Zn}$ and Fe yield of the various genotype groups evaluated here was, respectively, 20-30, and 27-50 adults/ha and year, with high values for wheat and landrace wheat and low values for oats and barley (Table 7). Significant differences were noted for nutrient density among the evaluated groups, with highest nutrient density (least amount needed to be consumed to obtain the daily recommended intake) found in oats and ancient wheat for the combination of Fe and $\mathrm{Zn}$ (Table 7). Yield of the genotype groups varied with mean values from 2330 to $3550 \mathrm{~kg} \mathrm{ha}^{-1}$ and grain protein content varied also significantly with values from 11.0 to $13.3 \%$ (Table 7). A significantly negaitve Pearson correlation $(p<0.005)$ was found between yield and grain protein concentration.

Table 7. Means of total yield $\left(\mathrm{kg} \mathrm{ha}^{-1}\right)$, protein content (\%), Fe and Zn nutritional yield (NY; adults/ha/year) and nutrient density (ND; amount in g needed to be consumed to achieve $100 \%$ of the daily recommended intake) of spring cereal groups cultivated in four different locations over three years.

\begin{tabular}{ccccccc}
\hline Source & Yield & Protein & Zn NY & Fe NY & Zn ND & Fe ND \\
\hline Rye & $2330^{\mathrm{b}}$ & $11.4^{\mathrm{b}, \mathrm{c}, \mathrm{d}}$ & $22.3^{\mathrm{a}, \mathrm{b}}$ & $32.0^{\mathrm{a}, \mathrm{b}}$ & $197^{\mathrm{b}, \mathrm{c}}$ & $283^{\mathrm{b}, \mathrm{c}}$ \\
Oats & $2790^{\mathrm{b}}$ & $11.6^{\mathrm{c}, \mathrm{d}}$ & $22.8^{\mathrm{b}}$ & $27.8^{\mathrm{b}}$ & $205^{\mathrm{b}}$ & $254^{\mathrm{c}}$ \\
Wheat & $3060^{\mathrm{a}, \mathrm{b}}$ & $12.2^{\mathrm{a}, \mathrm{b}, \mathrm{c}}$ & $27.9^{\mathrm{a}}$ & $49.8^{\mathrm{a}}$ & $214^{\mathrm{b}}$ & $303^{\mathrm{b}}$ \\
Ancient wheat & $2830^{\mathrm{b}}$ & $13.3^{\mathrm{a}}$ & $20.9^{\mathrm{b}}$ & $33.8^{\mathrm{a}, \mathrm{b}}$ & $175^{\mathrm{c}}$ & $279^{\mathrm{b}, \mathrm{c}}$ \\
Naked barley & $2580^{\mathrm{b}}$ & $13.1^{\mathrm{a}, \mathrm{b}}$ & $26.0^{\mathrm{a}, \mathrm{b}}$ & $33.3^{\mathrm{a}, \mathrm{b}}$ & $218^{\mathrm{b}}$ & $277^{\mathrm{b}, \mathrm{c}}$ \\
Barley & $350^{\mathrm{a}}$ & $11.0^{\mathrm{d}}$ & $21.5^{\mathrm{b}}$ & $27.3^{\mathrm{b}}$ & $270^{\mathrm{a}}$ & $344^{\mathrm{a}}$ \\
Landrace wheat & $3040^{\mathrm{a}, \mathrm{b}}$ & $12.3^{\mathrm{a}, \mathrm{b}, \mathrm{c}, \mathrm{d}}$ & $30.4^{\mathrm{a}}$ & $41.9^{\mathrm{a}}$ & $201^{\mathrm{b}, \mathrm{c}}$ & $277^{\mathrm{b}, \mathrm{c}}$ \\
\hline
\end{tabular}

Numbers followed by the same letters within a column do not differ significantly by the use of Tukey post-hoc test at $p<0.05$.

\section{Discussion}

The present study clearly showed specific genotypes, of the locally adapted spring cereal landraces and ancient genotypes grown organically, with high content of minerals and high nutrient density, although the variation among genotypes, cultivation locations and years were striking with 1.5- to 15-fold differences. The high mineral content genotypes depicted contribute opportunities to select mineral-rich genotypes for local production of nutritive food alternatives to be used e.g., in the New Nordic Diet, and also for breeding of novel high-nutrient cereals. Generally, the oats genotypes showed the highest minerals content, while ancient wheat showed high content of $\mathrm{Zn}$ and Fe. High content of minerals were also found, e.g., in the wheat genotype Diamant brun, the wheat landrace genotype Öland and the Hulless 2row barley genotype, and in particular when grown in Alnarp.

The large differences in content of various minerals shown in the samples evaluated here correspond well with previous results [32], which have proven that the selection of a wide array of genetic material and a spread of cultivation environments will result in a large variation in any type of compound analyzed in the plant material. Previous studies have indicated cultivation location as a major contributor to the minerals content in the cereal grain, although genetic impact on the minerals content has also been described previously, as well as genotype $x$ environment interactions [13,14,32,43-45]. However, the present investigation has clearly depicted the importance of the genotypes on the minerals content and composition. In the present study, covering minerals content of a wide array of Nordic traditional cereals, genotypes were outlined as the most important source for the mineral variation of all minerals except $\mathrm{Zn}$ and $\mathrm{Cu}$, for which cultivation location showed a higher percentage of explanation. Similarly, the genotype groups showed a higher percentage of explanation than the environmental factors (location and year) for all minerals except $\mathrm{Zn}$, $\mathrm{K}, \mathrm{Fe}$ and $\mathrm{Cu}$. In particular for $\mathrm{K}$, but also to a high extent for $\mathrm{Zn}$ and $\mathrm{Cu}$, the cultivation year showed a high percentage of explanation indicting the importance of taking also this source into consideration when evaluating minerals content in spring cereals. Thus, to secure a full understanding of the mineral variation in a broad cereal genetic material 
grown over several locations and years, use of multivariate statistical methods are required with potential to compare sample variation over all sources.

Previous studies [32] have indicated the width of the parameters (how broad genetic variation and how dispersed cultivation environments that are used) as the predictor for the importance of each of the parameters. Here, the genotypic material (various cereal types) might be judged as representing a broader width than the cultivation locations (spread across Sweden). Differently than in most studies, e.g., [13,14,32,45-52], the present study showed limited interactions between genotypes, cultivation location and cultivation year for the variation in minerals content and composition in the cereals evaluated. The absence of genotype by environment interactions indicate that individual that are genetically alike is expected to be homogenous independent of cultivation environment [53]. In the present investigation, the 12 genotypes being the same in all four cultivation environments are from various genotype groups with unequal number of each type. If genotypes from the same genotype group is seen as clusters, each genotype within a cluster (genotype group) can be expected to vary more similar over environments to genotypes within the same cluster than to genotypes within other clusters. Thus, the selection of the genotypic material in the present study might explain the lack of genotype $x$ environment interactions seen for the 12 genotypes grown and analyzed across all environments. This also explains the more common behavior with genotype $\mathrm{x}$ environment interactions that was found for genotype groups $x$ environments. However, due to the unbalanced character of the genotype groups in the present study (e.g., the rye group consisted of one genotype while oats and wheat consisted of 6-8 genotypes per location), multivariate statistical methods and treatments to overcome such issues are a necessity.

From the large variation in the content of different minerals depicted in the present study, specifically high contents of minerals were found both in certain cereal groups and in specific genotypes. Thus, the oat genotypes were here, generally found with a high content of minerals, and high content of $\mathrm{Zn}, \mathrm{Fe}, \mathrm{Mg}$ and $\mathrm{Cu}$ were generally noted for the ancient wheat genotypes across all four cultivation environments and years. Among the minerals, Fe and $\mathrm{Zn}$ are considered the most important in relation to human health [8,43]. A high content of $\mathrm{Zn}$ and Fe in ancient wheat grown in Sweden has also been reported in previous publications $[13,14]$. The levels reported here in ancient spring genotypes are somewhat lower as compared to values reported for winter wheat grown during the same period and in the same locations [14] but somewhat higher than in a mixed material of spring and winter genotypes grown during a somewhat earlier period of time [14]. High levels of Fe and Zn has consistently been reported in wild emmer wheat genotypes [43], and in diploid wheat, quantitative traits loci (QTL) for Zn and Fe content have been mapped to chromosomes 2A and 7A [44]. Thus, the findings in the present study of high contents of Fe and $\mathrm{Zn}$ in Nordic ancient spring wheat genotypes correspond well with previous findings on a broad range of ancient wheat.

Oats have in previous studies been identified as a functional food, due to its high content of soluble fiber, lipids, proteins, vitamins, minerals and phytochemicals such as polyphenols [54]. A recent study on mineral content in white oat genotypes from Brazil, reported a wide range of minerals content, with Fe values from 38 to $63 \mathrm{mg} / \mathrm{kg}$ and Zn values from 27 to $67 \mathrm{mg} / \mathrm{kg}$ [54] which also correspond to the variation in earlier studies $[34,55,56]$. Thus, the oats genotypes evaluated here did not outperform the best oat genotypes determined in previous studies for $\mathrm{Zn}$ and Fe content. Most of the oat genotypes in the present study did neither show the highest $\mathrm{Zn}$ and Fe values among samples evaluated here, although many of the oat genotypes evaluated showed generally high and stable minerals content, including all 10 minerals evaluated and across all cultivation locations and years.

The barley genotypes evaluated in the present study, consistently showed the lowest mineral contents among the samples. However, most previous investigation report even lower values for barley and also for rye, for content of Zn, Fe and most other minerals [55], than reported in this study. Furthermore, the naked barley genotypes in the present study, 
showed generally higher mineral contents than was found for the barley genotypes, with especially high levels of $\mathrm{Na}$. Mineral contents in naked barley from other studies are lacking. The differences in mineral content between barley and naked barley might be explained by the pearling of the barley, which is not necessary for naked barley.

The present study was also able to pin point high performing genotypes as well as high performing genotype groups across all cultivation location and years and those with more local adaptation, performing well in a certain cultivation location. Thus, the oat genotypes Engelbrekt (black oat) and Virma (white oat) showed high mineral levels across all cultivation location and the ancient wheats Emmer Gotland and Spelt wheat Gotland showed high $\mathrm{Zn}$ ad Fe content across all locations. The wheat genotype Diamant brun, the wheat landrace Öland and the hulless 2row barley were among those genotypes performing well in a certain location, e.g., Alnarp. Previous studies have shown variants of the landrace Öland with high mineral content and high content of carotenoids [13,15]. An adaptation over a wide array of environments is favorable for traditional breeding of high value characters in approved cultivars although local adaptation might be favorable for local production of high value genotypes for certain products.

Corresponding with previous results [13], the cultivation location Ekhaga contributed a higher mineral content, especially of $\mathrm{Zn}, \mathrm{Fe}, \mathrm{Cu}, \mathrm{Ca}$ and $\mathrm{S}$ to the samples. The major difference in the present study, of Ekhaga compared to the other localities was a difference in $\mathrm{K}-\mathrm{Al}$, with significantly higher values in Ekhaga, which was also the case in the previous study carried out on wheat during 2001-2007 [13]. The K-Al value in the soil describes the availability of $\mathrm{K}$ in the soil for the plant, which may enhance the minerals uptake.

The nutritional yield (e.g., Zn NY for wheat $=28$, Fe NY for wheat $=50$ ) of the spring genotypes evaluated here was generally lower, specifically for $\mathrm{Zn}$, as compared to corresponding values for winter wheat ( $\mathrm{ZnNY}=46-52$, Fe NY $=37-54$ ) reported earlier [14]. These differences can easily be explained by the generally lower yield always found for spring as compared to winter wheat when grown in the Nordic countries. Due to the low yield, winter cereals are often preferred by the grower but spring cereals can be an alternative due to harsh winter conditions hampering the winter cereal cultivation and also for the specific quality attributes that can be found in spring cereals, e.g., improved baking quality in wheat $[5,6]$. However, the yield difference between winter and spring wheat, makes comparisons of nutritional yield rather unbalanced. Studies on nutritional yield in spring wheat is currently lacking, and is reported for the first time for Nordic spring cereals. Furthermore, comparing the nutritional yield of the spring cereals in the present study with nutritional yield in cereals in an international context clearly shows the potential of the genotypes presented here. Thus, international data on the nutritional yield reports both Zn NY and Fe NY of 20-25 adults/ha and year for oats, 5-7 for wheat and 15-20 for barley and rye [57], and the corresponding numbers of the material presented here are 22-28 for oats, 28-50 for wheat and 21-37 for barley and rye. The differences in nutritional yield can be explained by differences in the genetic material and the cultivation conditions where organic cultivation of traditional genotypes might contribute to high values [10], while total yield (e.g., varying largely in wheat production) is also a contributing factor in the calculation of nutritional yield.

Similarly to has been described for traditional and organically produced winter wheat [14], the present study on traditional and organically produced spring wheat, showed favorable nutrient density in the wheat samples as compared to conventionally produced wheat $[58,59]$. Here, comparable nutrient densities to wheat were also shown for the rest of the genotype groups evaluated, with the exception of barley. Thus, locally adapted and organically produced cereals is a highly nutritional worthy alternative for the Nordic countries.

Cereals are the major staple for a large proportion of the worlds' population, contributing more than $40 \%$ of the daily calories and protein needed by the human population [1]. Due to the high intake, a shift towards cereals which are more highly nutritious and nutrient dense than those currently consumed will contribute a major change for human 
health. The present study verifies the opportunity to select and cultivate locally adapted and sustainably (organically or low-input) cultivated cereals with high minerals content and nutrient density that would benefit human health through its nutritional value.

Combining the use of high nutrient density cereals with a shift to a healthy diet such as the "Mediterranean" or the "Novel Nordic Diet (NND)" would add additional nutritional health to the human population. The NND suggests a transition to an increased amount of local and organically produced whole grain cereals in the diet for increased sustainability combined with improved human health [60]. Recent reports clearly show a change in the dietary intake in the Swedish population [61]. Less raw products such as flour, potatoes, sugar etc. are consumed and instead higher processed products are prioritized. Also, consumption of rice and pasta have increased on the cost of primarily potatoes. Table 8 shows a comparison of the contribution of minerals from $250 \mathrm{~g}$ (which is enough for the coverage of the daily requirements for most of the genotype groups of the present study) of different types of products, including the wheat genotypes analyzed here. In addition, we have included one product defined here as the NND mix. The NND suggests a transition towards whole grain products, to local production and to a consumption of less refined products [60]. The NND will also gain nutritional importance by the use of a combination of cereals. The oats, the ancient wheat, and some genotypes of wheat, landrace wheat and naked barley were found here as the most mineral rich and dense genotypes/genotype groups. However, other studies to come will probably show other important nutritional characters in genotypes other than those being the most mineral rich/dense.

Table 8. Contribution to four of the most essential minerals in the human diet by $250 \mathrm{~g}$ of the product and a comparison with the daily recommended intake (DRI).

\begin{tabular}{ccccc}
\hline \multirow{2}{*}{ Product } & \multicolumn{4}{c}{ Minerals (mg) } \\
\cline { 2 - 5 } & Zn & Fe & Mg & Cu \\
\hline Rice [62] & $3-11$ & $0.2-7$ & $22-62$ & $0.8-6$ \\
Pasta [63] & $3-6$ & $9-25$ & $107-145$ & $0.4-0.8$ \\
White flour [64] & $1-3$ & $2-3$ & $44-65$ & $0.4-0.7$ \\
Conventional whole grain wheat [58,59] & $4.3-7.3$ & $8-10$ & $224-320$ & $0.9-1.2$ \\
Whole grain wheat (present study) & 9.6 & 10 & 320 & 1.3 \\
NND mix [present study] & 10 & 11 & 329 & 1.3 \\
DRI [65] & 8 & 12 & 315 & 0.9 \\
\hline NND mix $=25 \%$ rye $125 \%$ oats $125 \%$ wheat $125 \%$ &
\end{tabular}

\section{Conclusions}

Mineral content and composition vary considerably in locally adapted and organically grown landraces and ancient genotypes of spring cereals, with clearly high values in certain genotypes and genotype groups. The genotypes and genotype groups were of significant importance to determine the content and composition of the minerals in the grain. However, to determine the content of certain minerals, e.g., $\mathrm{Zn}$ and $\mathrm{Cu}$, cultivation location played a larger role than the genotypes. In addition, the cultivation year was of significance for the content of some minerals, e.g., $\mathrm{K}$ and $\mathrm{Cu}$. The oats showed in general the highest mineral content although ancient wheats showed the highest content of $\mathrm{Zn}$ and Fe. Specific genotypes, e.g., the wheat genotype Diamant brun, the landrace wheat genotype Öland and the hulless 2row barley genotype was found with high mineral as well as $\mathrm{Zn}$ and Fe content when grown in Alnarp, due to the local climate of the most Southern cultivation location included, including cultivation temperature, precipitation, day-length and soil conditions. Although lower that in comparable winter wheat genotypes grown at the same locations, the nutritional yield of the spring cereals were generally high in an international context. Furthermore, all evaluated genotype groups, with the exception of barley, showed a high nutrient density. The use of either e.g., the wheat grains or a mix of genotypes from the different genotype groups in the New Nordic Diet concept, will contribute more or less the daily requirement of the most important minerals ( $\mathrm{Zn}$, 
$\mathrm{Fe}, \mathrm{Cu}, \mathrm{Mg}$ ), by the consumption of $250 \mathrm{~g} \mathrm{day}^{-1}$. Thus, as a source of mineral nutrition, the spring cereals evaluated here, outperform most other popular food products, which they have the potential to replace, such as rice, pasta, white flour, whole grains from conventional production. A mix in the food of the different genotype groups evaluated is suggested to secure also other nutritive compounds beside the minerals, and whole grain and less processed products should be taken into consideration, following the NND recommendations to secure presence and availability of the minerals.

Supplementary Materials: The following are available online at https:/ /www.mdpi.com/2304-8 158/10/2/393/s1, Figure S1: score (a) and loading (b) plot from principal component analysis of mineral content in 12 spring cereal genotypes; Table S1: Mean values over three years of content of the various minerals, yield and grain protein content for the genotypes grown at each location; Table S2: Pearson correlation coefficients between evaluated minerals.

Author Contributions: Conceptualization, E.J. and H.L.; methodology, H.L.; formal analysis, E.J., H.L. and M.L.P.-L.; investigation, H.L. and M.L.P.-L.; resources, E.J.; writing-original draft preparation, E.J.; writing-review and editing, H.L. and M.L.P.-L.; project administration, E.J.; funding acquisition, E.J. All authors have read and agreed to the published version of the manuscript.

Funding: This research was funded by EkoForsk and the Ekhaga Foundation. Compilation of the data was carried out as a part of the COST Sourdomics-Action.

Data Availability Statement: The datasets generated for this study are available on request to the corresponding author.

Conflicts of Interest: The authors declare no conflict of interest.

\section{References}

1. Shiferaw, B.; Smale, M.; Braun, H.-J.; Duveiller, E.; Reynolds, M.; Muricho, G. Crops that feed the world 10. Past successes and future challenges to the role played by wheat in global food security. Food Sec. 2013, 5, 291-317. [CrossRef]

2. FAO Food and Agriculture Organization of the United Nations. FAOSTAT Database; FAO: Rome, Italy, 2019.

3. Pena-Bautista, R.J.; Hernandez-Espinosa, N.; Jones, J.M.; Guzman, C.; Braun, H.J. Wheat-based foods: Their global and regional importance in the food supply, nutrition and health. Cereal Foods World 2017, 62, 231-249. [CrossRef]

4. Andersen, V.; Bar, E.; Wirtanen, G. Nutritional and Health Aspects of Food in Nordic Countries; Elsevier, Academic Press: Amsterdam, The Netherlands, 2018; ISBN 978-0-12-809416-7.

5. Peltonen-Sainio, P. Crop Production in a Northern Climate. FAO. Available online: www.fao.org/3/i3084e/i3084e15.pdf (accessed on 18 December 2020).

6. Spring Wheat, Lantmännen. Available online: https://www.lantmannenseed.com/varieties/spring-wheat (accessed on 18 December 2020).

7. Shafie, F.A.; Rennie, D. Consumer perceptions towards organic food. Procedia Soc. Behav. Sci. 2012, 49, 360-367. [CrossRef]

8. Johansson, E.; Hussain, A.; Kuktaite, R.; Andersson, S.C.; Olsson, M.E. Contribution of organically grown crops to human health Int. J. Environ. Res. Public Health 2014, 11, 3870-3893. [CrossRef]

9. Zaccone, C.; Di Caterina, R.; Rotunno, T.; Quinto, M. Soil-farming system-food-health: Effect of conventional and organic fertilizers on heavy metal (Cd, Cr, Cu, Ni, Pb, Zn) content in semolina samples. Soil Till. Res. 2010, 107, 97-105. [CrossRef]

10. Niederlie, P.; Schubert, M.N. How does veganism contribute to shape sustainable food systems? Practices, meanings and identities of vegan restaurants in Porto Alegre, Brazil. J. Rural Stud. 2020, 78, 304-313. [CrossRef]

11. Reisch, L.; Eberle, U.; Lorek, S. Sustainable food consumption: An overview of contemporary issues and policies. Sust. Sci Pract. Ploicy 2013, 9, 7-25. [CrossRef]

12. Pelletier, J.E.; Laska, M.N.; Neumark-Sztainer, D.; Story, M. Positive attitudes towards organic, local, and sustainable foods are associated with higher dietary quality among young adults. J. Acad. Nutr. Diet. 2013, 113, 127-132. [CrossRef] [PubMed]

13. Hussain, A.; Larsson, H.; Kuktaite, R.; Johansson, E. Mineral composition of organically grown wheat genotypes: Contribution to daily minerals intake. Int. J. Environ. Res. Public Health 2010, 7, 3442-3456. [CrossRef] [PubMed]

14. Moreira-Ascarrunz, S.G.; Larsson, H.; Prieto-Linde, M.L.; Johansson, E. Mineral nutritional yield and nutrient density of locally adapted wheat genotypes under organic production. Foods 2016, 5, 89. [CrossRef] [PubMed]

15. Hussain, A.; Larsson, H.; Kuktaite, R.; Olsson, M.E.; Johansson, E. Carotenoid content in organically produced wheat: Relevance for human nutritional health on consumption. Int. J. Env. Res. Public Health 2015, 12, 14068-14083. [CrossRef]

16. Zamaratskaia, G.; Gerhardt, K.; Wendin, K. Biocheical characteristics and potential applications of ancient cereals-An underexploited opportunity for sustainable production and consumption. Trends Food Sci. Technol. 2021, 107, 114-123. [CrossRef]

17. Hamnér, K.; Kirchmann, H. Trace element concentrations in cereal grain of long-term field trials with organic fertilizer in Sweden. Nutr. Cycl. Agroecosyst. 2015, 103, 347-358. [CrossRef] 
18. Martinez-Ballesta, M.C.; Dominguez-Perles, R.; Moreno, D.A.; Muries, B.; Alcaraz-Lopez, C.; Bastias, E.; Garcia-Viguera, C.; Carvajal, M. Minerals in plant food: Effect of agricultural practices and role in human health. A review. Agron. Sustain. Dev. 2009, 30, 295-309. [CrossRef]

19. Welch, R.M. The impact of mineral nutrients in food crops on global human health. Plant Soil 2002, 247, 83-90. [CrossRef]

20. Grusak, M.A.; DellaPenna, D. Improving the nutrient composition of plants to enhance human nutrition and health. Annu. Rev. Plant. Physiol. Plant Mol. Biol. 1999, 50, 133-161. [CrossRef]

21. Welch, R.M.; Graham, R.D. Breeding for micronutrients in staple food crops from a human nutrition perspective. J. Exp. Bot. 2004, 55, 353-364. [CrossRef] [PubMed]

22. Nyachoti, S.; Adebayo, S.; Godebo, T.R. Elemental composition of staple cereal crops in the Main Ethiopian Rift Valley. J. Food Comp. Anal. 2020, 103660. [CrossRef]

23. Skendi, A.; Papageorgiou, M.; Irakli, M.; Katsantonis, D. Presence of mycotoxins, heavy metals and nitrate reisdues in organic commercial cereal-based foods sold in the Greek market. J. Cons. Prot. Food Saf. 2020, 15, 109-119. [CrossRef]

24. Winiarska-Mieczan, A.; Kowalczuk-Vasilev, E.; Kwiatowska, K.; Kwiecien, M.; Baranowska-Wójcik, E.; Kiczorowska, B.; Klebanuik, R.; Samoli 'nska, W. Dietary intake and content of $\mathrm{Cu}, \mathrm{Mn}, \mathrm{Fe}$, and $\mathrm{Zn}$ in selected cereal products marketed in Poland. Biol. Trace Elem. Res. 2019, 187, 568-578. [CrossRef] [PubMed]

25. Giannenas, I.; Nisianakis, P.; Sarakatsianos, I.; Bonos, E.; Christaki, E.; Florou-Paneri, P. Trace and major elements content of cereal and proteinaceous feeds in Greece analyzed by inductively coupled plasma mass spectrometry. In Food Quality: Balancing Health and Disease, Handbook of Food Bioengineering; Holban, A.M., Grumezescu, A.M., Eds.; Academic Press: London, UK , 2018; pp. 197-223.

26. Brizio, P.; Benedetto, A.; Squadrone, S.; Curcio, A.; Pellegrino, M.; Ferrero, M.; Abete, M.C. Heavy metals and essential elements in Italian cereals. Food Add. Contamin. Part B 2016, 9, 261-267. [CrossRef]

27. Teklic, T.; Loncaric, Z.; Kovacevic, V.; Singh, B.R. Metallic trace elements in cereal grain-A review: How much metal do we eat? Food Energy Sec. 2013, 2, 81-95. [CrossRef]

28. Velu, G.; Singh, R.; Huerta-Espino, J.; Pena, J.; Ortiz-Monasterio, I. Breeding for enhanced Zinc and Iron concentration in CIMMYT spring wheat germplasm. Czech J. Plant Breed. 2011, 47, S174-S177. [CrossRef]

29. Velu, G.; Sing, R.P.; Crespo-Herrera, L.; Juliana, P.; Dreisigacker, S.; Valluru, R.; Stangoulis, J.; Sohu, V.S.; Mavi, G.V.; Mishra, V.K.; et al. Genetic dissection of grain zinc concentration in spring wheat for mainstreaming biofortification in CIMMYT wheat. Sci. Rep. 2018, 8, 13526. [CrossRef]

30. Velu, G.; Singh, R.P.; Huerta-Espino, J.; Pena, R.J.; Arun, B.; Mahendru-Singh, A.; Mujahid, M.J.; Sohu, V.S.; Mavi, G.S.; Crossa, J.; et al. Performance of biofortified spring wheat genotypes in target environments for grain zinc and iron concentration. Field Crops Res. 2012, 137, 261-267. [CrossRef]

31. Velu, G.; Herrera, L.C.; Guzman, C.; Huerta, J.; Payne, T.; Singh, R.P. Assesing genetic diversity to breed competitive biofortified wheat with enhanced grain Zn and Fe concentrations. Front. Plant Sci. 2019, 9, 1971. [CrossRef] [PubMed]

32. Johansson, E.; Branlard, G.; Cuniberti, M.; Flagella, Z.; Hüsken, A.; Nurit, E.; Peña, R.J.; Sissons, M.; Vazquez, D. Genotypic and environmental effects on wheat technological and nutritional quality. In Wheat Quality for Improving Processing and Human Health; Igrejas, G., Ikeda, T., Guzmán, C., Eds.; Springer: Cham, Switzerland, 2020; pp. 171-204.

33. Rubene, D.; Kuka, P. Minerals in oats, barley and wheat grains. In Research for Rural Development; Latvia University of Agriculture: Jelgava, Latvia, 2007; 319p.

34. Rodelhutscord, M.; Rückert, C.; Maurer, H.P.; Schenkel, H.; Schipprack, W.; Knudsen, K.E.B.; Schollenberger, M.; Laux, M.; Eklund, M.; Siegert, W.; et al. Variation in chemical composition and physical characteristics of cereal grains from different genotypes. Arch. Anim. Nutr. 2016, 70, 87-107. [CrossRef]

35. Mithril, C.; Dragsted, L.O.; Meyer, C.; Tetens, I.; Biltoft-Jensen, A.; Astru, A. Guidelines for the New Nordic Diet. Public Health Nutr. 2012, 15, 1941-1947. [CrossRef] [PubMed]

36. Mithril, C.; Dragsted, L.O.; Meyer, C.; Tetens, I.; Biltoft-Jensen, A.; Astru, A. Dietary composition and nutrient content of the New Nordic Diet. Public Health Nutr. 2013, 16, 777-785. [CrossRef] [PubMed]

37. Olsen, A.; Egeberg, R.; Christensen, J.; Overvad, K.; Tjonneland, A. Healthy aspects of the Nordic Diet are related to lower total mortality. J. Nutr. 2011, 141, 639-644. [CrossRef] [PubMed]

38. Adamsson, V.; Reumark, A.; Fredriksson, I.-B.; Hammarström, E.; Vessby, B.; Johansson, G.; Risérus, U. Effects of a healthy Nordic diet on cardiovascular factors in hypercholesterolaemic subjects: A randomized controlled trial (NORDIET). J. Intern. Med. 2011, 269, 150-159. [CrossRef]

39. Delin, S.; Soderstrom, M. Performance of soil electrical conductivity and different methods for mapping soil data from a small dataset. Acta Agr. Scand. Sect. B Soil Plant 2003, 52, 127-135. [CrossRef]

40. Malik, A.H.; Kuktaite, R.; Johansson, E. Combined effect of genetic and environmental factors on the accumulation of proteins in the wheat grain and their relationship to bread-making quality. J. Cereal Sci. 2013, 57, 170-174. [CrossRef]

41. Vazquez, D.; Berger, A.; Prieto-Linde, M.L.; Johansson, E. Can nitrogen fertilization be used to modulate yield, protein content and bread-making quality in Uruguayan wheat? J. Cereal Sci. 2019, 85, 153-161. [CrossRef]

42. Mukamuhirwa, A.; Hovmalm, H.P.; Ortiz, R.; Nyamangyoku, O.; Prieto-Linde, M.L.; Ekholm, A.; Johansson, E. Effect of intermittent drought on grain yield and quality of rice (Oryza sativa L.) grown in Rwanda. J. Agron. Crop Sci. 2020, 206, 252-262. [CrossRef] 
43. Peleg, Z.; Cakmak, I.; Ozturk, L.; Yazici, A.; Jun, Y.; Budak, H.; Korol, A.B.; Fahima, T.; Saranga, Y. Quantitative trait loci conferring grain mineral nutrient concentrations in durum wheat $x$ wild emmer wheat RIL population. Theor. Appl. Genet. 2009, 119, 353-369. [CrossRef] [PubMed]

44. Tiwari, V.K.; Rawat, N.; Chhuneja, P.; Neelam, K.; Aggarwal, R.; Randhawa, G.S.; Dhaliwal, H.S.; Keller, B.; Singh, K. Mapping of quantitative trait loci for grain iron and zink concentration in diploid A genom wheat. J. Hered. 2009, 6, 771-776. [CrossRef]

45. Joshi, A.K.; Crossa, J.; Arun, B.; Chand, R.; Trethovan, R.; Vargas, M.; Ortiz-Monasterio, I. Gentype x environment interaction for zinc and iron concentration of wheat grain in eastern Gangetic plains of India. Field Crops Res. 2010, 116, 268-277. [CrossRef]

46. Hristov, N.; Mladenov, N.; Djuric, V.; Konkic-Spika, A.; Marjanovic-Jeromela, A.; Simic, D. Genotype by environment interactions in wheat quality breeding programs in southeast Europe. Euphytica 2012, 174, 315-324. [CrossRef]

47. Johansson, E.; Svensson, G.; Tsegaye, S. Genotype and environment effects on bread-making quality of Swedish grown wheat cultivars containing HMW glutenin subunits $2+12$ or $5+10$. Acta Agric. Scand. 2000, 49, 225-233.

48. Koppel, R.; Ingver, A. Stability and predictability of baking quality of winter wheat. Agron. Res. 2010, 8, 637-644.

49. Malik, A.H.; Prieto-Linde, M.L.; Kuktaite, R.; Andersson, A.; Johansson, E. Individual and interactive effects of cultivar maturation time, nitrogen regime and temperature level on accumulation of wheat grain proteins. J. Sci. Food Agric. 2011, 91, 2192-2200. [CrossRef] [PubMed]

50. Rozbicki, J.; Ceglińska, A.; Gozdowski, D.; Jakubczak, M.; Cacak-Pietrzak, G.; Mądry, W.; Golba, J.; Piechociński, M.; Sobczyński, G.; Studnicki, M.; et al. Influence of the cultivar, environment and management on the grain yield and bread-making quality in winter wheat. J. Cereal Sci. 2015, 61, 126-132. [CrossRef]

51. Johansson, E.; Nilsson, H.; Mazhar, H.; Skerritt, J.; MacRitchie, F.; Svensson, G. Seasonal effects on storage proteins and gluten strength in four Swedish wheat cultivars. J. Sci. Food Agric. 2002, 82, 1305-1311. [CrossRef]

52. Andersson, S.C.; Rumpunen, K.; Johansson, E.; Olsson, M.E. Tocopherols and tocotrienols in Sea Buchthorn (Hippophae rhamnoides L.) berries during ripening. J. Agric. Food Chem. 2008, 56, 6701-6706. [CrossRef]

53. Baye, T.M.; Abebe, T.; Wilke, R.A. Genotype-environment interactions and their translational implications. Per. Med. 2011, 8, 59-70. [CrossRef]

54. De Oliveira Maximino, J.V.; Barros, L.M.; Pereira, R.M.; de Santi, I.I.; Aranha, B.C.; Busanello, C.; Viana, V.E.; Freitag, R.A.; Batista, L.; de Oliveira, A.C.; et al. Mineral and fatty acid content variation in white oat genotypes grown in Brazil. Biol. Trace Elem. Res. 2020, 199, 1194-1206. [CrossRef]

55. Bityutskii, N.; Yakkonen, K.; Loskutov, I. Content of iron, zinc and manganese in grains of Triticum aestivum, Secale cereal, Hordeum vulgare and Avena sativa cultivars registered in Russia. Genet. Resour. Crop Evol. 2017, 64, 1955-1961. [CrossRef]

56. Jãkobsone, I.; Kantãne, I.; Zute, S.; Jansone, I.; Bartkevičs, V. Macroelements and trace elements in cereal grains cultivated in Latvia. Proc. Latv. Acad. Sci. Sect. B Nat. Exact Appl. Sci. 2015, 69, 152-157.

57. DeFries, R.; Fanzo, J.; Remans, R.; Palm, C.; Wood, S.; Anderman, T.L. Metrics for land-scarce agriculture. Science 2015, 349, 238-240. [CrossRef]

58. Oury, F.-X.; Leenhardt, F.; Rémésy, C.; Chanliaud, E.; Duperrier, B.; Balfourier, F.; Charmet, G. Genetic variability and stability of grain $\mathrm{Mg}, \mathrm{Zn}$ and Fe concentrations in bread wheat. Eur. J. Agron. 2006, 25, 177-185. [CrossRef]

59. Lundegårdh, B.; Jastrebova, J.; Zhokhov, S.; Mårtensson, A.; Öborn, I. Effects of Growing Location and Variety on Free Tryptophan and Mineral Nutrient Content in Wheat; Latvia University of Agriculture, Faculty of Agriculture: Jelgava, Latvia, 2009 ; pp. $21-27$.

60. Meltzer, H.M.; Brantesaeter, A.L.; Trolle, E.; Eneroth, H.; Fogelholm, M.; Ydersbond, T.A.; Birgisdottir, B.E. Environmental sustainability perspectives of the Nordic diet. Nutrients 2009, 11, 2248. [CrossRef] [PubMed]

61. Statistik Från Jordbruksverket. Livsmedelskonsumtionen 1960-2006 (Consumption of Food 1960-2006). Statistikrapport 2009:2. (In Swedish). Available online: https://djur.jordbruksverket.se/webdav/files/SJV/Amnesomraden/Statistik, \%2 Ofakta/Livsmedel/2009_2/20092_amk_ihopb.pdf (accessed on 30 December 2020).

62. Jiang, S.L.; Wu, J.G.; Thang, N.B.; Feng, Y.; Yang, X.E.; Shi, C.H. Genotypic variation of mineral elements contents in rice (Oryza sativa L.). Eur. Food. Res. Technol. 2008, 228, 115. [CrossRef]

63. Belaggia, R.; Fragasso, M.; Miglietta, F.; Cattivelli, L.; Menga, V.; Nigro, F.; Pecchioni, N.; Fares, C. Mineral composition of durum wheat grain and pasta under increasing atmospheric $\mathrm{CO}_{2}$ concentrations. Food Chem. 2018, 242, 53-61. [CrossRef]

64. Vignola, M.B.; Moiraghi, M.; Salvucci, E.; Baroni, V.; Pérez, G.T. Whole meal and white flour from Argentine wheat genotypes: Mineral and arabinoxylan differences. J. Cereal Sci. 2016, 71, 217-223. [CrossRef]

65. Nordic Council of Ministers. Nordic Nutrition Recommendations 2012: Integrating Nutrition and Physical Activity, 5th ed.; Nordic Council of Ministers: Copenhagen, Denmark, 2012. 